Darie, B. (2021). The Art of Acting: intercrossing borders between science and art. Scientific view on the modern problems of cultural heritage and arts in the context of social development. Klironomy, 1 (01), 138-149. Hlučín-Bobrovníky: "Anisiia Tomanek" OSVČ.

Darie, B. (2021). Arta Actoriei: convergența limitelor dintre ştiință şi artă. Scientific view on the modern problems of cultural heritage and arts in the context of social development. Klironomy, 1 (01), 138-149. Hlučín-Bobrovníky: "Anisiia Tomanek" OSVČ.

DOI: $10.47451 / \operatorname{art} 2021-04-004$

EOI: $10.11249 / \operatorname{art} 2021-04-004$

The paper is published in Crossref, Internet Archive, Google Scholar, Academic Resource Index ResearchBib, JGate, ISI, CiteFactor, ICI, eLibrary databases.

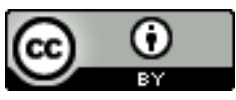

\author{
Bogdana Darie \\ Professor univ., PhD in Theatre and Performance \\ Head of Acting Department \\ Faculty of Theatre \\ National University of Theatre and Film "I.L. Caragiale" \\ Bucharest, Romania \\ E-mail: bogdana.darie@unatc.ro
}

\title{
The Art of Acting: intercrossing borders between science and art
}

\section{Abstract:}

The article aims to present professor's Ion Cojar method regarding the methodology of approaching the actor`s art from the point of view of the teaches who form future actors that are well trained, reaching both theoretical and practical dimensions. The purpose of the paper is to outline the fact that the art of acting is not something done by instinct or guided by emotions and spontaneous reactions, but, behind the scenes, lies a well-developed method, tested across many generations of students that combines psychology, aesthetics, critical thinking and acting practices. Blending old and new methods, creating a link between what was tested and what can be used in the future, the techniques used in the process of training the student from The National University of Theatre and Film "I.L. Caragiale" proved to be relevant in creating professionals that can operate in the artistic and scientific fields. In today's context, there has to be a shift of paradigm in the way people see the art of theatre, that can no longer be treated only from the aesthetic point of view. Acting methods can be used in the educational process and in raising the well-being of future generation by combining them with work models that make appeal to scientific data, offering to the future actor a larger domain to explore and develop.

Keywords: acting, psychology, self, scientific knowledge, methods, theatre. 
Profesor univ. dr. în Teatru și Artele Spectacolului Director Departament Arta Actorului Facultatea de Teatru Universitatea Națională de Artă Teatrală şi Cinematografică „I.L. Caragiale”

București, România

E-mail: bogdana.darie@unatc.ro

\section{Arta Actoriei: convergența limitelor dintre ştiință şi artă}

\section{Abstract:}

Articolul are în vedere analiza metodei profesorului Ion Cojar cu privire la metodologia de lucru în abordarea artei actorului din punctul de vedere al profesorului care formează actori antrenați atât din punct de vedere teoretic cât şi practic. Scopul materialului este acela de a sublinia faptul că actoria nu este o întâmplare, un proes care se ghidează după instinct, emoție sau reacție spontană, ci în spatele cortinei se ascund metode de lucru bine analizate de-a lungul anilor, care combină arta actorului cu psihologia, estetica, şi gândirea critică. Îmbinând metode noi şi vechi, metodele folosite în antrenarea studenților de la specializarea arta actorului, ai Universităţii de Artă Teatrală şi Cinematografică „I.L.Caragiale”, s-au dovedit a fi eficiente în formarea profesioniş̧ilor care pot opera atât ca artişti cât şi ca cercetători. În contextual lumii de astăzi, trebuie să existe o schimbare de paradigmă în ceea ce privește modul în care lumea tratează universul teatral, la care nu se mai poate face apel doar datorită valorii sale estetice. Instrumentele teatrale pot fi folosite în procesul de educare şi de creşterea a calităţii vieții a generațiilor viitoare, combinându-le cu modele de lucru care fac apel la explorarea instrumentelor şi informațiilor ştiințifice, oferind astfel astfel viitorului actor un domeniu mai vast de explorare şi dezvoltare.

Cuvinte cheie: actorie, psihologie, sine, cunoaştere ştiintifică, metode, teatru.

\section{Introduction}

In the context of today's possibilities and limitations theatre still needs to find its way in order to meet both the actor's and the audience's needs. Even though theatre means a convergence of arts, the present paper is focused on the art of acting, moreover on the science of teaching acting not as a mystical field but as a subject that enhances human potentials. Starting from 2020, theatre was accepted as an optional subject in the pre-academic educational system. In order to succeed into these project syllabuses had to be created that fitted the needs of the pupil from primary, gymnasium and high school that were in accordance with their psychological and biological development and with the rest of the subjects that they are studying. So, the syllabuses "The stage and I, Theatre and $u s$ " and "Theatre laboratory" are the most meaningful examples regarding the 
importance of approaching the art of acting from an interdisciplinary point of view. Even though the Ministry of education of Romania had accepted the introduction of theatre as a subject, the implementation of the project has not reached its target. There is a big need of teachers that are able to teach this subject. Thus, actors need to develop a new skill, the ability of explaining their own craft to others, taking into consideration their level of education and needs.

The study aims to analyses the process of teaching acting starting from Ion Cojar's belief that theatre and acting are two different things and in order to understand them we need to be specific and study them apart. While theatre covers the entire field of performance and representation, drama implies the study of the acting process starting from the core of the human being. It is important to have actors that are well aware of the exercises that they use, the concepts that they joggle with in order to contribute to the process of raising the well-being of a society. Based mostly on empirical research, the paper outlines the importance of scientific knowledge in triggering the creative nature of a person. Old acting techniques are used as references in order to prove their efficiency in the modern context in which professionals are looking to decompose the acting process using not only qualitative but also quantitative data. The study puts into the spotlight some acting methods that are at the convergence between art and cognitive sciences in order to emphasis the fact that acting, and furthermore the actor, can be used as a curative instrument for society, especially in the context of Covid-19 virus.

\section{The Actor's Art is firstly a specific logical mechanism}

The view of Professor Ion Cojar on the coexistence of sense and sensibility within the space of artistic creation is already known. Contrary to the idea of classical logic (which accepted the dichotomy: either sense or sensibility), the actor's art involves, at the same time, both thought and emotion. And the professor went further in claiming that an actor in the moment of authentic creation is a person with two or more identities. Thus, in the modern view, the founding principle of the Actor's Art is the mentality which functions based on the plurivalent logical scheme which accepts and explains logically, coherently, the multiple, polyvalent nature of the authentic actor. They are both the creator and their work, at the same time; they are the actor (the civilian), as well as the character (whose concept and way of thinking they have adopted). How 
much of the behavior belongs to one or the other cannot be measured with precision, they in fact become a unity, an irreducible totality which can no longer be dismantled.

As the Actor's Art professor Ion Cojar wrote in his book A Poetics of the Actor's Art, the phenomenon of artistic creation typical of actors: "is a way of thinking. The Actor's Art is firstly a specific logical mechanism. It is only secondly that the actor's art is a way of 'doing"' (Cojar, 1998).

The actor is the one who brings to life latent virtual potentialities out of the sphere of their own polyphonic individuality. In theatre, the 'authentic' actor achieves, creates, brings within the sphere of reality that which is merely potential. "The character of the dramatic text is nothing but a semiotic system. In order for them to become a living, material system, one which is embodies, brought forward into actuality" (Cojar, 1998), writes Ion Cojar; in other words, actualization is the specific action, the process undergone by the actor or, more precisely, the phenomenon that takes place with their own being. The actor's art is directly and inextricably linked to being, as well as to transforming.

The difference between true and false within the art of the authentic actor consists of the concrete difference between 'to be' or 'not to be' inside an essential process. "The artists - once they have offered their instruments to thoughts and feeling, the whole sensorial apparatus, through the transfer of concepts from themselves to the character with the help of substitutive imagination - has practically nothing more to work with in order to correct themselves, to better their acts, their gestures, their behaviors throughout the existential itinerary of the character they have taken on, except at the risk of breaking the chain of the creative process" (Cojar, 1998). Exact, identical repetition on stage of experiences and reactions on stage does not lead to an authentic artistic process. Each 'repetition' must be a new journey, a redoing of a road of discovery. The actor who relies on mechanical rendition, on stereotyping, will end up lying to themselves, not using, in fact, their own creative potential. What is more, imitation, copying and mechanical reproduction, according to previous models, cannot result in a valuable artistic product.

The universe of the characters' inner experiences cannot be known in its essence except through one's own experimentation. It is the only way that an authentic actor can take. Sacrificing experimentation on oneself must take place each time, with each exercise, as the discovery of other identities or human structures that they are called upon to take on and for whom they must substitute themselves, can only be done, 
paradoxically, through their own individuality, through their own psychosomatic 'totality', through their own identity, professor Ion Cojar maintains.

The phenomenon of accessing one of the unknown but possible egos of the human actor generates the miraculous component of the authentic stage act. Even though theatre itself is a convention, and the world built on stage is fictional, through the art of the authentic actor, these become significant truths under our very eyes; and what is more, characters that come to life on stage reveal possible psychological realities.

The word enriched the actor's art with culture, but led it further from its own essence, for at its core are nonverbal means of expression and communication. An extra degree of theorizing sometimes leads to the dismantling of the process of creation up to the point where it is impossible to find the unity that generates the initial spontaneity. Excessive censorship of reason can shake the balance of living phenomena, of the settling of the actor's behavior up to the point of diminishing subjectivity, the specific natural particularities which ensure the originality, the uniqueness of each individual, states Ion Cojar.

The Actor's Art does not merely consist of 'saying a text', but rather of the discovery and actualization of their own essential possibilities in different life situations, precisely individualized, as well as of the physical and intellectual manifestation, which becomes significant through the contribution of psychological experiences. "The actor's art is invention and discovery; it is fiction and truth at the same time. The genius of the actor does not only invent, but it discovers, it does not assemble, or arrange, but it reveals, it actualizes preexistent and inexhaustible possibilities from within themselves" (Cojar, 1998), says professor Cojar; this means that the art of the authentic actor offers the possibility of rediscovering an elementary truth, namely that the human being carries within themselves the premises of theatricality through their very contradictory nature, on all levels, psychological, somatic, and physical.

Discussing the effort that the actor must make in order to reach the 'other' (the character that the playwright merely suggests), professor Ion Cojar states that the way to 'them' - the character goes through myself (the actor); for as soon as I have found myself (meaning, when I have become me, the unmistakable), I can be the 'others' (many? few?) that I could potentially be. It is only by first taking on myself, I can take on the dimensions of 'the other' towards whom I am headed. Ultimately, writes professor Ion Cojar, all characters are within ourselves and (n.b.) the way to them has three distinct causeways that (paradoxically) intersect: Myself in given situations; Myself 
in the process of discovering my purpose, my role in the stage convention; Myself having become a character through substitution, but after taking on the concept, the logical mechanism typical of the character.

\section{Exercises}

The exercise that bears the generic name Animals is part of the group of exercises the purpose of which is knowing the logical mechanism typical of the character. It is undergone together with the exercises: human with animal character, Concept and Interview.

In the accepted meaning of modern orientations in theatre, the Concept is the integrating element within which we can find the generic pattern of the character. Being a 'static element by definition' (Lupasco, 1982), the concept uses an actioning ensemble called mentality; due to it, the rigours of the concept begin to take shape. That actioning ensemble called 'mentality' 'brings to life' the typical logical mechanism.

Finding, defining the coordinates of the concept are what leads the actor - creator towards establishing the dimensions of the character.

But the quasi-stable character of individual psychological life makes an exact, fixed concept of the character impossible to establish. And this is because the concept it, in the view of Stephane Lupasco, the owner of a paradoxical 'static movement'. This idea means that, in fact, the concept if potentially dynamic. In his 'Poetics...', professor Ion Cojar notes that "Psychological phenomena do not have a linear development, they do not always have motivations, causes that we can establish" (Cojar, 1998).

It is at this stage that the inside dimension of the actor intervenes with its possible inconsistency, its sensitivity, the range of general culture, the motivation, the attitude towards artistic creation etc. All of these can influence the discovery of a logical mechanism typical of the character, potentially different from individual to individual. "The interview is also a type of exercise through which one can control the degree to which the person substituted by the actor is embodied. The generic pattern of the character is the concept, the intimate logic which is typical of the character into which the author's logic has been converted" (Cojar, 1998).

This type of 'concept' exercises, of discovery and taking on the logical mechanism typical of characters, is also applied to animal study.

The basic structure of the exercise is made up of two stages: the detailed study of an animal's behavior (chosen by the student), aiming for the discovery, the 
understanding of the type of thinking, of action (whether in extreme, tensioned situations, or in a relaxed state), of relations to other animals (whether of the same species or different ones); the discovery of the possibilities of existence in various media; the student is invited to substitute themselves for the animal through taking on its typical logical mechanism.

The main purpose of this exercise is for the student - actor to understand the concrete difference between the attempt to substitute by taking something upon themselves and the temptation to imitate.

We will remark on the following: if we ask students to think about an animal, a dog for instance, each of them will not see a dog in general, but rather they will particularize it according to their own experience, to their own representations. This is why each actor will think of a particular breed, body type etc. At this point the 'dog concept' becomes dynamic and different from one student to the other.

Thus, when working with future actors it is important to anchor their flux of emotions and states of mind with exercises that can enable them the power of understanding the process of becoming a real artist with a specific technique.

\section{Searching for the Truth. Empirical and scientific knowledge}

All these exercises make up the integrating principle of Stanislavski: "From the outer truth of the life of the body to the inner truth of the life of the spirit" (Stanislavski, 2013). But what does 'the outer truth of the life of the body' mean: reality; how can we know reality and how can we turn it into the 'new reality of the life of the spirit'?

In the view of the Russian actor, director and professor K.S. Stanislavsky, the founder of the preparation System of the servant of the stage, truth is hidden within the deepest depths of the soul of the actor. It is only thusly that the exposed, presented truth will shake emotions through the unforeseen, through the connection to the forgotten depths of the pat, through creating landmarks for those yet to come and through the novel logic of life, even though it does not appear to have a clear purpose on first sight.

These spiritual states, difficult to describe in words, such as: allusions, forebodings, contradictory states etc., will be accompanied by our great questions, doubts, anxieties, religious beliefs etc. That is where there undoubtedly lies a sensitive 'field' from where two paths can be taken: either the ardent burning of the feelings from which memorable creation is brought to life, or the (placid) quietness that leads to artistic cancelling! One 
must find an unconditional balance between talent, intuition (on one hand) and the technique of interpretation (on the other hand). It is only this way that creation will take shape: it is only this way that impressions on the show will be unique, unmistakable, unrepeatable.

Every evening one will have a chance to impress the spectator, but each time it will be different, it will be something else. Why? Because every evening, one will reach the subconscious through different inner paths of the conscious; this path (difficult and unpredictable) forms the true bases of dramatic art. One can safely say that this is what the essential difference between actors and artisans consists of, the latter only create if they are well guided and inspired, while actors must filter their inspiration and, becoming aware of their own experiences and behaviors, step into the (bizarre and vast) area of the subconscious, 'coming out' towards the audience differently, with other 'clothes'; it is only at this point that they will be credible and applauded. For the spectator does not (really) want to see their own face in its authentic image on stage, but rather the inner dimension that they barely suspect and that they perhaps even fear.

In the psychological field of the creative life, one could say that all actors feed on impressions and sensations that they preserve in their emotional or intellectual memory. All of these are processed in the subconscious with the help of their artistic fantasy. It is a minute work of transfiguration, which leads (if successful) to forming an aesthetic image. On an individual level, the true super - conscious dimension of the creation of each actor stands all chances of remaining a secret that is difficult to solve, as it is not merely the outlining, embodying, and presenting a literary character which is interesting, but the way in which it 'starts' from the actor and is revealed to us at a certain point, in a show, at a certain point of this show, on one particular evening... There is also the chance that on a different evening, in the same show, the actor that embodies the same literary character will find different solutions, have different reactions, surprising even to themselves. It all depends on the degree to which the unconscious creative stimuli are present. And this is because the act of creation is endless and eternal.

Stanislavski's system is based, as he himself declared, on highlighting the organic nature of the actor. Essentially, the Stanislavsky's principle presupposes a deep knowledge of the immediate reality, and after deciphering any dramatic situation, taking it on by starting from reality, so that the theatre show does not become an illusion, but another reality. 
All exercises of knowing reality presuppose exercises that reactivate the senses (taste, sight, smell, hearing, touch), help one integrate within a group, stimulate attention, reaction, memory, study and working with objects, as well as 'animal study'.

But what path do we choose in animal study, in understanding and then taking on the logical mechanism that is typical of them? There is only one critical path: the path of knowledge. But if we think at the term of knowledge, we will need to mention that this essentially entails two sides of knowledge: the scientific and the artistic one.

Prior to any approach we must remember an idea which has long been present in philosophical thinking: in the relationship between the ' $\mathrm{I}$ ' (that is, the subject, the person) and the 'Non-I' (that is, the objective world), the only one that is directly active is the $\mathrm{I}$, as this is the Consciousness: but a consciousness that results from the action (willful or not) of the outside world. In this action, the I impose their will, their attitudes, their concepts, their inner experiences, by inserting them into a reality that they build according to their plans, through practical action.

And this is how the two inseparable fields of human existence are founded: the theoretical and the practical. Because when we say "the I outlines the Non-I", we think practically, whereas when we say "The Non-I influences and limits the I", we mean it theoretically. However, the 'Non-I' is a product which results from the multiple ventures of the 'I', and practice, activity, and therefore freedom is what lays the foundation of the theoretical side of existence, turning it into an act of knowledge: except this way one reaches a paradox: because it pursues the taking on of the real, what any act of knowing does is in fact 'cancelling' the real; because it is being moved from the outside within the individual. This is, of course, one way of putting it, because without observing, analyzing, synthesizing etc. the information so avidly sought and obtained with great effort and sensitivity from 'the outside', the real would be not only a great illustrious unknown, but also a lacking essential parameter for the general development of the human.

However, what does know 'the real' mean?

Philosophical thinking has long established the idea according to which gnoseology or the theory of knowledge is the field in philosophy which studies the genesis, the nature and the range of human knowledge, its presuppositions and foundations. At the same time, it has been accepted that gnoseology is focused on the study of the totality of forms and means of human knowledge, whereas epistemology has been accepted as the philosophical theory of predominantly scientific knowledge. 
But when can we say that we know something? What makes a thought, a view, an opinion, worthy of being called knowledge?

A first condition would be for said opinion, view etc., to be true. But true by what criteria? Are scientific criteria enough to vouch for accumulated knowledge? It would appear not, since philosophers have introduced another essential condition: justification. In other words, we only know something if we have solid and sufficient reason to not only argue its validity, but also to justify (to ourselves, firstly) the effort, putting it under the empire of solid inner motives. Thusly, the premises necessary to convince others will be ensured. At this point, the knowing subject can step from thinking into action.

Thus, in the context of scientific knowledge, we wonder, is there a place for what could be called artistic knowledge? Having come from the wide sphere of scientific knowledge which, in fact, founds its ventures, artistic knowledge is, essentially, more of a state of the spirit and an elite aid of an individual's everyday life. One can say (with the help of Kant (Kant, 1987)) that through the beneficial effort of artistic knowledge, humans search for beauty, balance and ineffable in art, in order to then discover it within themselves.

Artistic knowledge also has an extremely important moral component as well as one of attitude, induced by the chromatic character, the phonic and the visual background generated by the ambiental immediateness within which the individual lives. The individual's capacity to 'lean' towards these outer stimuli, their desire to make them their own argues their vocation to want to be integrated in the ambient. Because the individual lives not only within a climate of material values, but also in an ambient strongly marked by spiritual values transformed into syntheses; these come back (abundantly or moderately) to the individual in the form of obvious manifestations. And the individual makes them their own, after a strict personal evaluation; it is at that point that they endow the real with aesthetic value.

Aesthetic values can be relative or absolute, positive or negative, fundamental or not, but all fall under the sign of the statement of Nicolai Hartman (Hartmann, 1974) according to which: there is a whole range of 'higher or lower' aesthetic values; the aesthetic value is given by the result of the process of practically - spiritual appropriation of the real (which includes nature and social life in its ensemble), while artistic value refers strictly to the universe of art, to the imagined artistic product, molded 
and created by the fantasy, anxiety, ambition and dedication that any creator must exhibit.

\section{Discussion}

Scientific research allows the modern person to better control their emotions and control the process of creation, so that it is no longer a random one, but one that is actively stimulated by the physical resort. Benedetto Croce mentions that "by elaborating impressions, one is released from them. By objectivizing them, they move further from them and becomes superior to them. The liberating and purifying function of art is another aspect and another way of phrasing its nature as an activity. The very reason activity is liberating is that it chases away passivity" (Croce, 1972). Furthermore, we need to establish a balance between control and the creative impulses. The questions "How we measure the impact of theatre on society? What is happening in the actor's brain?" and "How to we train professionals using a common work methodology?" are still open to be investigated. The study of the brain and neuronal structures explains to the actor how they convey emotion, connect with the partners and the audience, communicate nonverbally or get orientated in space. Research in the field of neuroscience facilitates the emergence of new paradigms of experimentation in the field of theatre and raises several questions regarding the human impact on cognition. Space research, for example, has reached new levels, researchers Edvard I. Moser, May-Britt Moser and Bruce L. McNaughton announce. "After almost 50 years since the place cells were discovered, these and their homologue in the para hippocampus have become some of the most important tools in understanding the cortical calculus and spatial mapping, as well as in understanding in mechanical terms the cognitive function of navigation" (Moser, Britt Moser, McNaughton, 2017). The progress of science determines the progress of people, the understanding of the functioning mechanisms and thus, the progress of the performing arts. O'Keffe has demonstrated that any "information about changing position and direction in space can be calculated from animal movements" (O'Keffe, 1976), which backs the importance of studying acting in an interdisciplinary way, in the process of discovering and analysing the way in which people work. Understanding these processes contributes to the development of an integrative vision of the actor's art and determines the formation of the modern artist. 


\section{Conclusion}

The act of creation (a purely human action) renders the human being noble, making it similar to the Great Demiurge. In the act of creation, the human is truly free. Nobody and nothing from the outside must be present at the process of creation of an artistic product. Otherwise, the artistic product is 'commissioned' and its aesthetic value decreases drastically.

The aesthetic value of an artistic product cannot only not be anticipated, it cannot be perfectly perceived by those on the outside even with the most judicious critical apparatus or the most successful game of an abundant intuition, until the author has considered their work finished; the emergence of the artistic product can cause a real aesthetic shock which will force the watcher ('the consumer' essentially) to return to it time and time again; and each contemplation will be different each time, as the joy that is felt will offer an opportunity for new inner syntheses, new ideas and aesthetic experiences. And this is because with each contemplation, look, participation etc., the psychological needs and expectations of the watcher will be different, as their aesthetic attitude will always be different, and the aesthetic taste (that is, the spontaneous reaction of pleasure, accepting or rejecting) that has already arrived in the sphere of controlled evaluation of inner experiences will receive its full rights.

It can be claimed that a first step in the superior founding of an artistic act is scientific knowledge. However, once this first step has been taken, once one has therefore arrived to the sphere of artistic knowledge, the real creator will have to appeal to the cultural dimension of their personality, their inner combustion and their whole personal universe of experiences, sensations and feelings. It is only these that can generate a valuable artistic creation.

\section{References:}

Adler, A. (2016). Inţelegerea vieții. Introducere in psibologia individuală. Bucharest: Trei.

Blair, R., Cook, A. (2016). Theatre Performance and Cognition. Language, bodies and Ecologies, Bloomsbury.

Carnike, S.M. (1989). Stanislavski in focus. London: Routledge.

Carruthers, P., Smith, P.K. (2011). Theories of theories of mind. Cambridge University Press. Cojar, I. (1998). A Poetics of the Actor's Art. Bucharest: Paideia.

Dewey, J. (2005). Art as Experience. New York: Perigee. 
Esslin, M. (1976). An Anatomy of Drama. London: Temple Smith.

Evans, D. (2006). An Introductory Dictionary of Lacanian Psychoanalysis. London: Routledge. Gardner, H. (2006). Multiple Intelligences. New York: Basic Books.

Hartmann, N. (1974). Aesthetics. Bucharest: Univers.

Heidegger, M. (2001). Poetry, Language, Thought. Harper Perennial.

Hess, E. (2016). Acting \& Being. Explorations in Embodied Performance. Palgrave Macmillan. Hethmon, R.H. (coord.). (1996). Strasberg at the Actors Studio. Tape-recorded sessions. New York: Viking Press.

Kant, I. (1987). Prolegomena. Bucharest: Ştiințifică şi Enciclopedică.

Lupasco, S. (1982). The Dynamic Logic of the Contradictory. Bucharest: Politică. Merleau-Ponty, M. (1992). Phenomenology of perception. London: Routledge.

Norbert, E. (2002) Procesul civilizării (Process of Civilization). Translated by Monica-Maria Aldea. Iaşi: Polirom Publishing House.

Stanislavski, K.S. (2013). An Actor's Work on Himself. Bucharest: Nemira. 